\title{
High Expression of Cyclooxygenase-2 in High Grade Human Prostate Adenocarcinoma
}

\author{
(Pengekspresan Tinggi Siklooksigenase-2 dalam Adenokarsinoma Prostat Manusia Gred Tinggi)
}

\author{
Mohd Rohaizad Md Roduan*, Norhafizah Mohtarkudin, Chong Pei Pei, \\ MALINA OSMAN \& NORAINI MOHD DUSA
}

\begin{abstract}
Inflammation plays an important role to the process of prostate carcinogenesis by increasing the rate of cell proliferation, which contributes to an aggressive tumour phenotype. Cyclooxygenase-2 (COX-2) has been found overexpressed in various types of cancer cells including prostate. The aim of this study was to investigate the COX-2 expressions in different types of human prostate tissues. Paraffin-embedded prostate tissues from 263 samples were examined for the expression of COX-2 marker by immunohistochemistry method. COX-2 was found highly expressed in prostate adenocarcinoma $(\mathrm{p}=0.001)$ as compared to benign and normal tissues. The score of COX-2 expressions in most of normal prostate was weak 49 (77.8\%), while only $16(16 \%)$ of BPH showed strong expression. 56 cases (56\%) prostate cancer showed strong COX-2 expression. Prostate cancer cases showed significant differences in staining patterns as tumour grade increased. In addition, COX-2 expression was significantly correlated with Gleason score in cancerous tissues. This study suggests that COX-2 overexpression is associated with prostate cancer and higher grade tumour.
\end{abstract}

Keywords: Cyclooxygenase-2 (COX-2); immunohistochemistry; inflammations; overexpression; prostate adenocarcinoma

ABSTRAK

Inflamasi memainkan peranan penting dalam proses pembentukan kanser prostat melalui peningkatan kadar pembahagian sel. Inflamasi juga bertanggungjawab dalam pembentukan fenotip kanser prostat yang lebih agresif. Siklooksigenase-2 (COX-2 didapati diekspres lebih tinggi daripada aras biasa dalam pelbagai jenis sel kanser termasuk prostat. Tujuan kajian ini dijalankan adalah untuk mengkaji pengekspresan COX-2 dalam tisu prostat manusia yang berbeza. Sebanyak 263 tisu prostat tertanam parafin telah digunakan untuk mengkaji aras pengekspresan penanda COX-2 melalui kaedah imunohistokimia. Pengekspresan COX-2 didapati lebih tinggi dalam tisu adenokarsinoma prostat $(p=0.001)$ berbanding tisu benigna dan tisu prostat yang normal. Kebanyakan tisu prostat normal mengekspres COX-2 yang lemah 49 (77.8\%) dan hanya 16 (16\%) tisu BPH menunjukkan pengekspresan COX-2 yang kuat. Manakala, 56 (56\%) tisu kanser prostat menunjukkan pengekspresan COX-2 yang kuat. Tisu kanser prostat juga menunjukkan perbezaan corak perwarnaan COX-2 yang signifikan dengan peningkatan gred tumor. Selain itu, pengekspresan COX-2 menunjukkan perhubungan yang signifikan dengan skor Gleason dalam tisu kanser. Kajian ini mencadangkan bahawa terdapat hubungan antara pengekspresan COX-2 yang sangat tinggi dengan kanser prostat dan tumor gred tinggi.

Kata kunci: Adenikarsinoma prostat; siklooksigenase-2 (COX-2); imunohistokimia; inflamasi; pengekspresan

\section{INTRODUCTION}

Prostate adenocarcinoma ( $\mathrm{PCa}$ ) is one of the most frequently diagnosed cancers among males in Malaysia. A report by National Cancer Registry (2008) showed that, prostate cancer is the fourth frequent cancer occurred and accounted for $7.3 \%$ of the total cancers occurrence among males. Out of total cases, the majority of morphologically reported cases were adenocarcinoma which is $96 \%$. Today diagnosis of prostate cancer is commonly based on morphological interpretation by use of cell architecture, nuclear features and presence or absence of basal cell layer. Nevertheless, this method is usually not adequate in equivocal cases in which it might require histopathologists to use immunohistochemistry (IHC) staining to resolve the differential diagnosis (Varma \& Jasani 2005). Despite of the clinical importance of prostate cancer, understanding of mechanism underlying development and progression of this disease is poorly understood. Many researches have suggested that inflammation was linked to the development of tumours in several organs, including the prostate itself (Weitzman \& Gordon 1993). Cyclooxygenase (COX), was referred as prostaglandin (PG) endoperoxidase synthase, is an enzyme that converts arachodonic acids to PGs and other eicosanoids. COX exists in two isoforms, namely COX-1 and COX-2. COX-1 is expressed constitutively in many tissues and cell types and involved in normal cellular physiological functions. Meanwhile, COX-2 exists as pro-inflammatory in nature and inducible by variety of factors, including growth factors, cytokines, tumour promoters and mitogens (Herschman 1991). Aberrant 
or increased expression of COX-2 has been described in most of human carcinomas such as gastric cancer, esophageal carcinoma, hepatocellular carcinoma, head and neck squamous cell carcinoma, lung carcinoma and breast carcinoma (Chan et al. 1999; Hwang et al. 1998; Kazuhiko et al. 1998; Koga et al. 1999; Wolff et al. 1998; Zimmermann et al. 1999) Additional studies showed elevated level of COX-2 induces cancer cell proliferation, inhibits apoptosis, promotes tumour cell vascularization, as well as increases metastatic potential (Kakiuchi et al. 2002; Sheng et al. 2001). Early studies on relationship of COX reported that COX-1 and COX-2 expression levels were found to be approximately equal in various human tissues (O’Neill \& Ford-Hutchinson 1993). In year 2000, a study which has been done in Japan proved that COX-2 was highly expressed in prostate adenocarcinoma compared to benign and normal prostate (Yoshimura et al. 2000). Song et al. (2002) demonstrated increased COX-2 expression in prostate cancer cells in vitro correlates with a decreased in the apoptotic index. Additionally, studies on animal models of prostate cancer suggested a link between arachidonic acid and its precursor, linoleic acid which is the major ingredient of animal fat and vegetable oils in diet that contribute to increase of risk of getting prostate cancer (Bosland et al. 1999). In this study, we aimed to examine the expression of COX-2 in series of normal, BPH and prostate adenocarcinoma cases using immunohistochemistry as a method to determine the role of COX-2 in prostate carcinogenesis and its possible associations with some clinocopathological parameters of malignant cases.

\section{MATERIALS AND METHODS}

\section{PATIENT SAMPLES}

A total of 263 paraffin embedded specimens were obtained between year 2006 and 2008. The specimens selected for this study consist of 63 normal prostate tissues, 100 each of BPH and PCa. Normal prostate were obtained from post-mortem of dead body which was died due to an accident. Whereas, the benign and prostate cancer tissues specimens were obtained from patient who underwent radical prostatectomy. Ethical approval was obtained from Research Ethic Committee of Universiti Putra Malaysia (UPM), National Medical Research Registration (NMRR) and HKL. The tumour histopathology was classified by Gleason grading and scored as low group; Gleason 6 to 7 and high group; Gleason 8 to 9. Tumour volume was classified as low amount, $\leq 5 \%$ and high amount, $>5 \%$. Pre-treatment PSA were grouped as either $\leq 4.0 \mathrm{ng} / \mathrm{mL}$ and $>4.0 \mathrm{ng} / \mathrm{mL}$.

\section{IMMUNOHISTOCHEMISTRY}

COX-2 immunohistochemistry staining was done using the DAKO REAL EnVision kit (Dako, Ca, USA). Formalin- fixed and paraffin-embedded blocks were sectioned at 4 $\mu \mathrm{m}$ thickness and preceded with Hematoxyline and Eosin (H \& E) staining to confirm the diagnosis before the immunohistochemistry procedure. Sections were mounted onto poly-L-lysine glass slide and dried overnight at room temperature. Then, sections were dewaxed with absolute xylene and rehydrated with gradient alcohol and lastly run under tap water. Antigens were retrieved by microwaving at $1000 \mathrm{~W}$ for $10 \mathrm{~min}$ high temperature followed by 10 min medium low temperature in citrate buffer $(0.01 \mathrm{M}, \mathrm{pH}$ 6.0). After cooled down at room temperature for $20 \mathrm{~min}$, sections endogenous peroxidase activity was inactivated in $3 \% \mathrm{H}_{2} \mathrm{O}_{2}$ for $5 \mathrm{~min}$. Then, sections were rinsed with phosphate buffer saline (PBS) 2 times for 5 min followed by $1 \mathrm{~h}$ incubation with monoclonal mouse anti-human COX-2 (clone CX-294, Dako, USA) at a dilution 1:100. Secondary antibody detection system (Dako, EnVision+ System-HRP labeled, Dako, USA) was added to the sections and incubated for $30 \mathrm{~min}$ at room temperature. Finally, diaminobenzidine (Dako, USA) was used as a chromogen to verify immunoreactions and followed by counterstaining by using hematoxylin. Negative control was processed simultaneously from the same samples and protocol but primary antibody step was replaced by antibody diluents. Colon adenocarcinoma sections were used as a positive control because this tissue is well known to express COX-2.

\section{COX-2 EXPRESSION ANALYSIS}

A representative area with 500 tumour cells was assessed for the positive and negative staining by two pathologists that were blinded from the original diagnosis. The degree of staining intensity scored was recorded as 0 to $4+$ by using ten randomly ocular fields under X200 magnification. The extent and intensity of positive tumour cells was graded as 0 , none; $1+$, weak; $2+$, moderate; $3+$, strong; and 4+, very strong (Yoshimura et al. 2000). Positive staining was considered if more than one percent of tumour cells stained and together with membranous, or cytoplasmic and/or diffuse (membranous + cytoplasmic) staining pattern were detected. Intensity score was further grouped as low $(0-2+)$ and high $(3+-4+)$ COX2 expression in order to see any association with the clinicopathological parameters. All slides were evaluated without any knowledge of the patient's information and clinical reports.

\section{STATISTICAL ANALYSIS}

Data were recorded and statistically analysed using SPSS for Windows Version 17.0 (Chicago, USA) and the statistical results were considered significant when the $\mathrm{P}$ value is less than 0.05 at $95 \%$ confidence intervals. Mann-Whitney test was used to compare the expression of COX-2 between normal, BPH and PCa. Chi-square test was also used to see the association between clinicopathological variables with COX-2 expressions. 


\section{RESULTS AND DISCUSSION}

Total specimens included in this study were in the ages of 28 to 91 (mean age, 64.54 \pm 10.8 years). Expression of COX-2 was compared between normal, BPH and PCa tissues. Of the total 100 PCa cases; 37 cases were Gleason 6, 37 cases had Gleason 7, 10 cases were Gleason 8 and the other 16 cases had Gleason 9 . There was constitutively weak COX-2 expression observed in all cases $(77.8 \%)$ of normal prostate. Weak expression was also seen in 84 cases $(84 \%)$ of BPH and 44 cases (44\%) of PCa. In contrast, strong COX2 expression was detected in 56 of PCa cases $(56 \%)$ with the score of $3+$ to $4+$. Only 16 cases $(16 \%)$ of BPH showed strong COX-2 expression. Whereas none of the normal prostate tissues showed strong COX-2 expression. There is a significant different of COX-2 expression bewteen normal, $\mathrm{BPH}$ and $\mathrm{PCa}, \mathrm{COX}-2$ expression was found constitutively greater in PCa $(p<0.001)$ than benign and normal prostate (Table 1). Three patterns of staining were found in COX2 expression, in which from membranous, cytoplasmic and diffuse (mix of both patterns). Staining pattern was concentrated around membrane of the cells and scattered into cytoplasmic region. COX-2 was expressed in glandular epithelial cells but not in the stroma (Figure 1(a)-1(f)).

Majority of normal prostate cases $(92.1 \%)$ and BPH $(76 \%)$ cases exhibited a membranous staining pattern. None of both cases however showed diffuse staining pattern. In contrast, 32 (32\%) PCa cases showed cytoplasmic staining and $28(28 \%)$ cases showed diffused staining pattern (Table 2). Membranous staining pattern was seen in $32(86.5 \%)$ in Gleason 6 cases whereas 21 $(56.8 \%)$ cases of Gleason 7 showed cytoplasmic staining pattern. In contrast, $6(60 \%)$ cases of Gleason 8 and 14 $(87.5 \%)$ cases of Gleason 9 exhibited diffused staining patterns (Table 3 ). Generally, variety of staining pattern exhibited in PCa cases was correlated with increasing tumour grade $(p=0.0001)$ (Table 3$)$.

Beside that, association between COX-2 expression with clinicopathological parameters (age, PSA level, Gleason score and tumour amount) was also studied and grouped into certain cut-off points (Wang et al.

TABLE 1. Distribution of COX-2 expression in normal, BPH and PCa cases

\begin{tabular}{|c|c|c|c|c|c|c|c|}
\hline \multicolumn{7}{|c|}{ Distribution of COX-2 staining intensity } & \multirow[t]{3}{*}{$p$} \\
\hline Score & 0 & 1 & 2 & 3 & 4 & \multirow[b]{2}{*}{ Total } & \\
\hline Tissue type & & & & & & & \\
\hline Normal & $0(0 \%)$ & $49(77.8 \%)$ & $14(22.2 \%)$ & $0(0 \%)$ & $0(0 \%)$ & $63(100 \%)$ & \\
\hline $\mathrm{BPH}$ & $7(7 \%)$ & $36(36 \%)$ & $41(41 \%)$ & $15(15 \%)$ & $1(1 \%)$ & $100(100 \%)$ & 0.001 \\
\hline $\mathrm{PCa}$ & 0 & $10(10 \%)$ & $34(34 \%)$ & $41(41 \%)$ & $15(15 \%)$ & $100(100 \%)$ & 0.000 \\
\hline
\end{tabular}
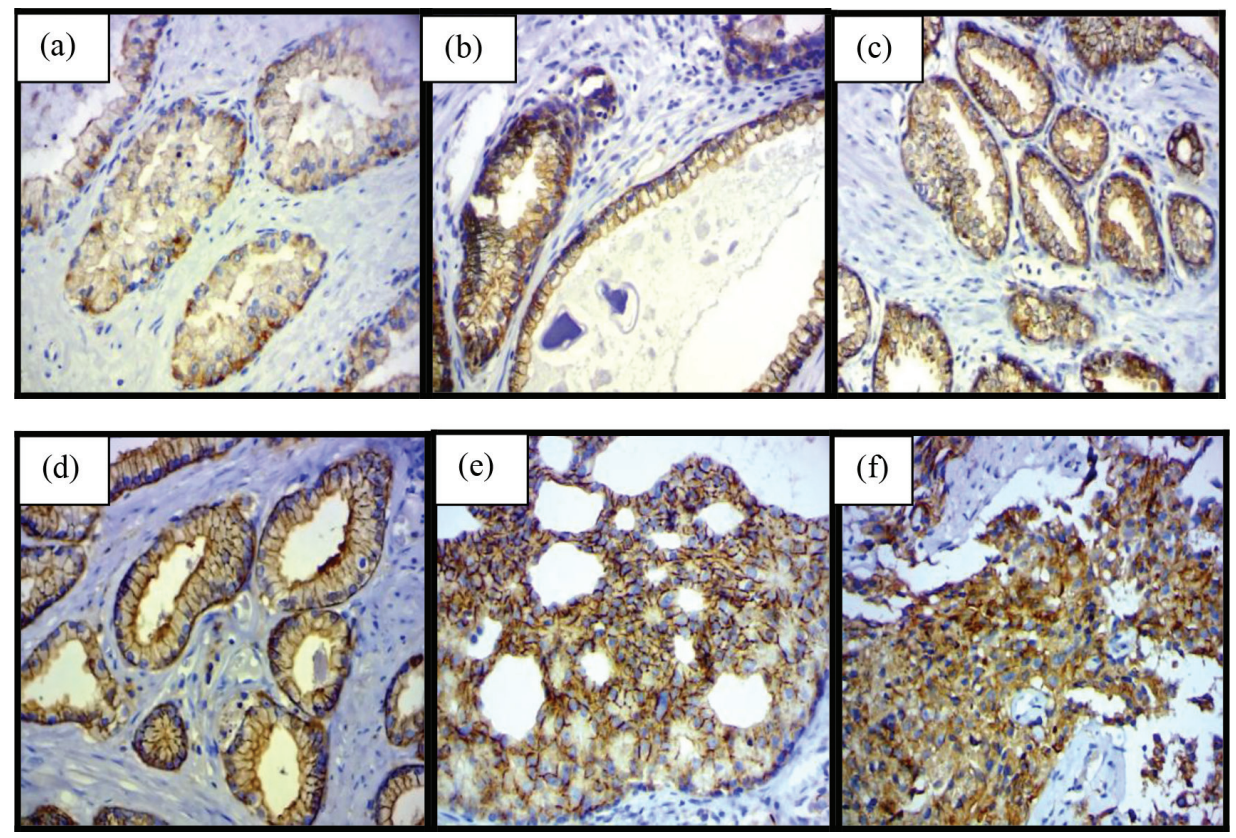

FIGURE 1. Immunohistochemical detection of COX-2 in human prostate tissues (X 200) (a) Normal prostate cell shows weak and membranous staining of COX-2, (b) BPH shows moderate membranous staining of COX-2, (c) PCa Gleason 6 shows weak and cytoplasmic staining of COX-2, (d) PCa Gleason 7 shows moderate to strong and membranous to cytoplasmic staining of COX-2, (e) PCa Gleason 8 shows strong and membranous and cytoplasmic staining of COX-2 and (f) PCa Gleason 9 shows a very strong and diffuse staining of COX-2 
TABLE 2. COX-2 staining pattern in normal, BPH and PCa cases

\begin{tabular}{lcccc}
\hline & \multicolumn{3}{c}{ Staining pattern distribution } \\
\cline { 2 - 4 } Case & Membranous & Cytoplasmic & $\begin{array}{c}\text { Diffuse } \\
\text { (membranous + cytoplasmic) }\end{array}$ & Total \\
\hline Normal & $58(92.1 \%)$ & $5(7.9 \%)$ & $0(0 \%)$ & $63(100 \%)$ \\
BPH & $76(76 \%)$ & $24(24 \%)$ & $0(0 \%)$ & $100(100 \%)$ \\
PCa & $40(40 \%)$ & $32(32 \%)$ & $28(28 \%)$ & $100(100 \%)$ \\
\hline
\end{tabular}

TABLE 3. COX-2 staining pattern in different grades of PCa

\begin{tabular}{cccccc}
\hline & \multicolumn{2}{c}{ Distribution of staining pattern } & & & \\
Gleason score & Membranous & Cytoplasmic & Granular & Total & $p$ \\
\hline 6 & $32(86.5 \%)$ & $5(13.5 \%)$ & $0(0 \%)$ & $37(100 \%)$ & \\
7 & $8(21.6 \%)$ & $21(56.8 \%)$ & $8(21.6 \%)$ & $37(100 \%)$ & $<0.001$ \\
8 & $0(0 \%)$ & $4(40 \%)$ & $6(60 \%)$ & $10(100 \%)$ & \\
9 & $0(0 \%)$ & $2(12.5 \%)$ & $14(87.5 \%)$ & $16(100 \%)$ & \\
\hline
\end{tabular}

2005). Staining intensity was correlated to Gleason score $(p=0.011)$ in which COX-2 expression was found significantly increased together with Gleason score (Table $4)$. There is a significant relationship seen between age group and COX-2 expression in BPH cases but none in PCa cases. There is no significant association between COX-2 expression and PSA level and tumour amount (Table 4).

COX-2 has been extensively studied in various disease and cancer including prostate cancer. In these current studies, COX-2 expression level was found significantly different in normal, BPH and PCa tissues. None of the normal cases showed strong COX-2 expression whereas all $(100 \%)$ of normal prostate cases showed weak COX-2 expression (1+ and $2+)$. In contrast, more than half (56\%) of PCa cases showed strong COX-2 expression (3+ and 4+).
The increased intensity of COX-2 staining was also seen with the increased of Gleason score (Figure 1(c)-1(f)). This finding suggested, increased COX-2 expression has a role in the aggressiveness of tumour phenotype in PCa. The present finding was closely similar to the study done by Yoshimura et al. (2000), who found that COX-2 expression was very weak in all BPH and normal prostate samples. They also found, a very strong COX-2 expression in the high grades of prostate adenocarcinomas. High COX-2 expression in PCa cases of this study was also paralleled to the latest study done in Egypt. They found that $86.7 \%$ of PCa cases showed strong COX-2 expression and PCa grade 3 cases showed COX-2 expression stronger than those of grade 2 with statistically significant (Mostafa et al. 2009). Consistent with our results, many studies indicated that

TABLE 4. Relationship between COX-2 expressions with clinicopathological parameters

\begin{tabular}{|c|c|c|c|c|}
\hline \multirow[t]{2}{*}{ Clinicopathological parameter } & \multicolumn{2}{|c|}{ COX-2 score } & \multirow[b]{2}{*}{ Total } & \multirow[b]{2}{*}{$p$} \\
\hline & $\begin{array}{l}\text { Low expression } \\
\qquad(0-2+)\end{array}$ & $\begin{array}{l}\text { High expression } \\
\qquad(3+-4+)\end{array}$ & & \\
\hline \multicolumn{5}{|c|}{ Age group in $\mathrm{BPH}$ (mean $68.13 \pm 7.42$ ) } \\
\hline$\leq 68$ years & 30 & 10 & 40 & 0.043 \\
\hline$>68$ years & 54 & 6 & 60 & \\
\hline \multicolumn{5}{|c|}{ Age group in $\mathrm{PCa}$ (mean $66.78 \pm 6.23$ ) } \\
\hline$\leq 66$ years & 17 & 23 & 40 & 0.100 \\
\hline$>66$ years & 27 & 33 & 60 & \\
\hline \multicolumn{5}{|l|}{ PSA (ng/mL) } \\
\hline$\leq 4.0$ & 13 & 16 & 29 & 0.915 \\
\hline$>4.0$ & 31 & 40 & 71 & \\
\hline \multicolumn{5}{|l|}{ Gleason score } \\
\hline$\leq 7$ & 36 & 38 & 74 & 0.011 \\
\hline$>7$ & 8 & 18 & 26 & \\
\hline \multicolumn{5}{|l|}{ Tumour amount (\%) } \\
\hline$\leq 5$ & 20 & 15 & 35 & 0.052 \\
\hline$>5$ & 24 & 41 & 65 & \\
\hline
\end{tabular}


COX-2 was expressed at high levels in PCa (Gupta et al. 2000; Liu et al. 2000; Wang et al. 2005).

In term of staining patterns, COX-2 staining pattern was differently expressed in normal, BPH and PCa cases. We found that, COX-2 was expressed from membranous, cytoplasmic to diffuse staining patterns in various prostate tissues. Interestingly, the membranous pattern expression was found in the luminal glandular cells of the majority of normal $(92.1 \%)$ and BPH $(76 \%)$ cases. In contrast, COX-2 expression in PCa was marginally greater tumour cells than in benign and normal cells. COX-2 expression in majority of PCa cases was showed heterogeneous from moderate to strong cytoplasmic and diffuse staining pattern. The pattern shift from membranous to diffuse within the PCa cases in which it was correlated with increasing tumour grade $(p<0.001)$. This finding was similar to the study done by Madaan et al. (2000) which they reported that aggressiveness of PCa was related to the staining pattern. They added, intracellular localization of COX-2 in the epithelial cells in BPH and PCa was different. PCa predominantly localized in the cytoplasmic region whereas BPH was mainly at the membrane region. This study supported Madaan et al. (2008) study in which Gleasons 8 and 9 showed more diffuse staining patterns as compared to the Gleason 6 which was membranous staining pattern. Naturally, COX-2 was expressed in cell membrane in the luminal cells of $\mathrm{BPH}$, which is consistent with the co-localization of the enzyme and its substrate. Linoleic acid is the major constituents of the lipid bilayer of the cell membrane and is a precursor of arachidonic acid, from which prostaglandins are, synthesized (Gottard 1986). This feature of COX-2 expression was lost during cellular transformation, as the expression became cytoplasmic and diffused (Madaan et al. 2008).

In addition, we also found that Gleason $>7$ cases showed higher COX-2 expression level than those cases with Gleason score $\leq 7$ with statistically significant $(p=0.01)$. Increased level of COX-2 expression in high grade PCa (Gleason > 7) was generally in line with previous studies (Gupta et al. 2000; Madaan et al. 2000; Wang et al. 2005; Yoshimura et al. 2000). However, there were discrepancies reported by Zha et al. (2001), as they mentioned that COX-2 expression was not consistently elevated in PCa but in proliferative inflammatory atrophy (PIA) of prostate, and furthermore, the extent of positive staining did not correlate with Gleason score. Another study also reported the same finding as Zha et al. (2001) although they found high COX-2 expression in high grade prostate tumour cells (Shappell et al. 2001). Age of BPH group was found correlated with COX-2 expression $(p=0.043)$, with the expression showed consistently low level in almost all BPH tissues but significantly increased with aging. In contrast, age of PCa group was not found correlated with COX-2 expression $(p=0.100)$. Furthermore, there was no significant association found between PSA level and tumour amount with the COX-2 expression. Although, PSA has been used for a long time in diagnostic consideration on PCa, however its sensitivity was not perfect enough to be used alone. PSA generally fails as a marker to evaluate the extent of tumor phenotype for prostate cancer (Rodney 2005). Tumour amount did not show any significant finding with the level of COX-2 expression, it is suggested due to the variability in interpretation of the tumour amount itself by pathologists during the histopathological procedure.

In addition, to prove evidence that COX-2 has a significant role in the prostate carcinogenesis and aggressiveness, we also provide different views in animal and cell culture studies that showed the same finding as what we have obtained. Hla et al. (1999) mentioned that prostaglandin (PG) production generally was elevated in cancer cells, suggesting that COX-2 induction has the potential in promoting tumour growth and its progression. Animal study showed COX-2/Apc ${ }^{\Delta 716}$ double-gene 'knockout' mice have lesser and smaller intestinal polyps than $\mathrm{Apc}^{4716}$ knockout mice. This study clearly showed that COX-2 is responsible for the aggressiveness of intestinal polyps phenotype in mice (Oshima et al. 1996). Liu et al. (1998) reported that a selective COX-2 inhibitor has a potential inducing apoptosis and down-regulates bcl2 expression in prostate cancer cell line ( $\mathrm{LNCaP}$ ). Latest study done by Hao et al. (2011) found that prostate cancer cell growth can be inhibited by directly inhibiting COX-2 expression. According to the report, tumour-supressive miRNA (miR-101) has a direct effect on inhibition of COX-2 expression. Besides, exogenous miR-101 also suppresses the proliferation and growth of prostate cancer cells in vivo and in vitro.

There are many evidences by which COX-2 plays a role in carcinogenesis either direct or indirect mechanism may be involved in prostate cancer development and progression. Many studies have been discussing on how over-expression of COX-2 can promote cell proliferation and metastasis of cancer cells (Hla et al. 1999). Prostaglandin production generally was elevated in most of cancer cells. Additionally, induction of COX-2 expression induces networks of regulatory factors that influence cell survival, growth and differentiation (Coussens \& Werb 2001). COX2 also induces vascularization (Chu et al. 2003; Leung et al. 2002; Wang et al. 2005). This process is important for tumour growth and metastases. Wang et al. (2005) mentioned that proinflammatory cytokines, released by T-lymphocyte and macrophages, up-regulate COX-2 in adjacent tumour cells and stimulate the angiogenesis in stromal tissues within prostate cancer. Direct relationship of angiogenesis between COX-2 and PCa was also consistent with observation in liver, colon, endometrial and breast tumour (Chapple et al. 2002; Davies et al. 2003; Fujiwaki et al. 2002; Rahman et al. 2001). Over-expression of COX-2 has also been implicated in up-regulation of bcl-2 expression and this leads to decrease in apoptosis (Tsujii et al. 1998). In contrast, down-regulation of bcl- 2 expression was reported when it is treated with a selective COX-2 inhibitor (NS-398) (Liu et al. 1998). Consistent with Liu et al. (1998), the latest study demonstrates that colorectal cancer cells undergo greater apoptosis as a result of exposure to specific COX-2 inhibitor in vivo (Rahman et 
al. 2012). On the other hand, COX-2 over-expression was also induced to the decreased expression of E-cadherin and thus promoting loss of cell-to-cell adhesion which would increase the chance in invasiveness of tumour (Tsujii \& DuBois 1995). Generally, E-cadherin plays a major part in the establishment and maintenance of intracellular adhesion and tissue architecture. Loss of E-cadherin mediated intercellular adhesion seems to be an important contributor factor in tumour metastasis.

\section{CONCLUSION}

In conclusion, the study proved that the over-expression of COX-2 has a significant association with prostate cancer and higher grade tumour. Although we did not see a significant association between COX-2 expression and clinicopathological parameters such as age, PSA and tumour amount, there was a clear significant finding that showed COX-2 expression was over-expressed in high grade cancer specimens. Additionally, the shift from membranous to cytoplasmic and diffuse staining pattern was correlated with neoplastic progression of prostate tissues from normal to benign and malignant prostate tissues. There are strong arguments and suggestions that COX-2 should be evaluated further as one of the potential therapeutic targets for prostate cancer or even other types of cancers in Malaysia. We also hope that this study might be useful as a baseline data to other studies in order to develop the best prognostic marker for prostate cancer.

\section{ACKNOWLEDGEMENTS}

This work was supported by Ministry of Education, Malaysia under FRGS scheme (vote: 5523327). We thank Hospital Kuala Lumpur for providing us the samples and not to forget the committee members for their contributions to make this study possible.

\section{REFERENCES}

Bosland, M.C., Oakley-Girvan, I. \& Whittemore, A.S. 1999. Dietary fat, calories and prostate cancer risk. J.Natl.Cancer Inst. 91: 489-491.

Chan, G., Boyle, J.O., Yang, E.K., Zhang, F., Sacks, P.G., Shah, J.P., Edelstein, D., Soslow, R.A., Koki, A.T., Woerner, B.M., Masferrer, J.L. \& Dannenberg, A.J. 1999. Cyclooxygenase-2 expression is up-regulated in squamous cell carcinoma of the head and neck. Cancer Res. 59: 991-994.

Chapple, K.S., Scott, N., Guillou, P.J., Coletta, P.L. \& Hull, M.A. 2002. Interstitial cell cyclooxygenase-2 expression is associated with increased angiogenesis in human sporadic colorectal adenomas. J. Pathol. 198: 435-441.

Chu, J., Llyod, F.L., Trifan, O.C., Knapp, B. \& Rizzo, M.T. 2003. Potential involvement of cyclooxygenase-2 pathway in the regulation of tumour associated angiogenesis and growth in pancreatic cancer. Mol. Cancer Ther. 2: 1-7.

Coussens, L.M. \& Werb, Z. 2001. Inflammatory cells and cancer: Think different! J. Exp. Med. 193: F 23- 26.

Davies, G., Salter, J., Hills, M., Martin, L.A., Sacks, N. \& Dowsett, M. 2003. Correlation between cyclooxygenase-2 expression and angiogenesis in human breast cancer. Clin. Cancer Res. 9: 2651-2656.

Fujiwaki, R., Iida, K., Kanasaki, H., Ozaki, T., Hata, K. \& Miyazaki, K. 2002. Cyclooxygenase-2 expression in endometrial cancer: Correlation with microvessel count and expression of vascular endothelial growth factor and thymidine phosphorylase. Hum. Pathol. 33: 213-219.

Gottard, S. 1986. Relevance of fatty acids and eicosanoids to clinical and preventive medicine. Prog. Lipid Res. 25: 1-4.

Gupta, S., Srivastava, M.,Ahmad, N., Bostwick, D.G. \& Mukhtar, H. 2000. Over-expression of cyclooxygenase-2 in human prostate adenocarcinoma. Prostate 42: 73-78.

Hao, Y., Gu, X., Zhao, Y., Stephen, G., Sha, W., Duane, T., Smoot, J.C., Wu, T.C. \& Xiaowu, P. 2011. Enforced expression of miR-101 inhibits prostate cancer cell growth by modulating the COX-2 pathway in vivo. Cancer Prev. Res. 4(7): 10731083.

Herschman, H.R. 1991. Primary response genes induced by growth factors and tumor promoters. Annu. Rev. Biochem. 60: 281-319.

Hla, T.A., Ristimaki \& Sano, H. 1999. Role of the early gene Cyclooxygenase-2 (COX-2) in angiogenesis. Cancer Res. 59: 2223-2228

Hwang, D., Scollard, D., Byrne, J. \& Levine, E. 1998. Expression of cyclooxygenase- 1 and cyclooxygenase- 2 in human breast cancer. J. Natl. Cancer Inst. 90: 455-460.

Kakiuchi, Y., Tsujii, S., Tsujii, M., Murata, H., Kawai, N., Yasumaru, M., Kimura, A., Komori, M., Irie, T., Miyoshi, E., Sasaki, Y., Hayashi, N., Kawano, S. \& Hori, M. 2002. Cyclooxygenase-2 activity altered the cell-surface carbohydrate antigens on colon cancer cells and enhanced liver metastasis. Cancer Res. 62: 1567-1572.

Kazuhiko, U., Ichikura, T., Mochizuki, H. \& Shinomiya, N. 1998. Expression of cyclooxygenase-2 protein in gastric adenocarcinoma. J. Surg. Oncol. 69: 168-172.

Koga, H., Sakisaka, S., Ohishi, M., Kawaguchi, T., Taniguchi, E., Sasatomi, K., Harada, M., Kusaba, T., Tanaka, M., Kimura, R., Nakashima, Y., Nakashima, O., Kojiro, M., Kurohiji, T. \& Sata, M. 1999. Expression of cyclooxygenase-2 human hepatocellular carcinoma: Relevance to tumor dedifferentiation. Hepatology 29: 688-696.

Leung, W.K., To, K.F., Go, M.Y., Chan, K.K., Chan, F.K., Ng, E.K., Chung, S.C. \& Sung, J.J. 2003. Cox-2 upregulates vascular endothelial growth factor expression and angiogenesis in human gastric carcinoma. Int. J. Oncol. 23: 1317-1322.

Liu, X.H., Kirschenbaum, A., Yao, S. \& Levine, A.C. 1998. NS398, a selective cyclooxygenase-2 inhibitor, induces apoptosis and down-regulates bcl-2 expression in $\mathrm{LNCaP}$ cells. Cancer Res. 58: 4245-4249.

Liu, X.H., Kirschenbaum, A., Yao, S., Lee, R., Holland, J.F. \& Levine, A.C. 2000. Inhibition of cyclooxygenase-2 suppresses angiogenesis and the growth of prostate cancer in vivo. J. Urol. 164: 820-825.

Madaan, S., Abel, P.D., Hewitt, R., Chaudhary, K.S., Stott, M.A., Stamp, G.W.H. \& Lalani, E.N. 2000. Cytoplasmic induction and overexpression of cyclooxygenase- 2 in human prostate cancer: Implications for prevention and treatment. $\mathrm{Br}$. $J$. Urol. 86: 736-741.

Mostafa, M.K., Samira, A.M., Samia, M.G. \& Moustafa, A.A.S. 2009. Cyclooxygenas-2 (COX-2) expression in Egyptian case of benign prostatic hyperplasia and prostatic adenocarcinoma. Acad. J. of Cancer Research 2: 33-39. 
National Cancer Registry. 3rd ed. Ministry of Health, Malaysia. 2008. Cancer Incidence in Peninsular Malaysia 2003 - 2005. Kuala Lumpur: National Printers Malaysia.

O’Neill, G.P. \& Ford-Hutchinson, A.W. 1993. Expression of mRNA for cyclooxygenase- 1 and cyclooxygenase- 2 in human tissues. FEBBS Lett. 330: 156-160.

Oshima, M., Dinchuk, J.E., Kargman, S.L., Oshima, H., Hancock, B., Kwong, E., Trzaskos, J.M., Evans, J.F. \& Taketo, M.M. 1996. Supression of intestinal polyposis in $\mathrm{Apc}^{\Delta 716}$ knockout mice by inhibition of Cyclooxgenase-2 (COX-2). Cell 87: 803-809.

Rahman, M., Selvarajan, K., Hasan, M.R., Chan, A.P., Jiri, C., Kim, J., Chen, S.K., Le, N.D., Kim, Y.B. \& Tai, I.T. 2012. Inhibition of COX-2 in colon cancer modulates tumour growth and MDR-1 expression to enhance tumour regression in therapy-refractory cancers in vivo. Neoplasia 14(7): 624633.

Rahman, M.A., Dhar, D.K., Yamaguchi, E., Maruyama, S., Sato, T., Hayashi, H., Ono, T., Yamanoi, A., Kohno, H.\& Nagasue, N. 2001. Coexpression of inducible nitric oxide synthase and COX-2 in hepatocellular carcinoma and surrounding liver: Possible involvement of $\mathrm{COX}-2$ in the angiogenesis of hepatitis C virus-positive cases. Clin. Cancer Res. 7(5): 1325-1332.

Rodney, T.M. 2005. Immunohistochemical markers of prostate carcinoma, including prostate-specific membrane antigen (PSMA). ProPath. Sep 13: 1-2.

Shappell, S., Manning, S., Boeglin, W., Guan, Y., Roberts, R., Davis, L., Olson, S., Jack, G., Coeffy, C., Wheeler, T., Breyer, M. \& Brash,A. 2001. Alteration in lipooxygenase and cyclooxygenase catalytic anctivity and mRNA expression in prostate carcinoma. Neoplasia 3: 287-303.

Sheng, H.J., Shao, M., Washington, M.K. \& DubBois, R.N. 2001. Prostaglandin E2 increases growth and motility of colorectal carcinoma cells. J. Biol. Chem. 276: 18075-18081.

Song, X.Q., Lin, H.P., Johnson, A.J., Tseng, P.H., Yang, Y.T., Kulp, S.K. \& Chen, C.S. 2002. Cyclooxygenase-2 player or spectator in cyclooxygenase-2 inhibitor-induced apoptosis in prostate cancer cells. J. Natl. Cancer Inst. 94: 585-591.

Tsujii, M. \& DuBois, R.N. 1995. Alterations in cellular adhesion and apoptosis in epithelial cells overexpressing prostaglandin endoperoxide synthase-2. Cell 83: 450-493.

Tsujii, M., Kawano, S., Tsuji, S., Sawaoka, H., Hori, M. \& DuBois, R.N. 1998. Cyclooxygenase regulates angiogenesis induced by colon cancer cells. Cell 93: 705-716.

Varma, M. \& Jasani, B. 2005. Diagnostic utility of immunohistochemistry in morphologically difficult prostate cancer. Histopathology 47: 1-16.

Wang, W., Bergh, A. \& Damber, J.E. 2005. Cyclooxygenase-2 expression correlates with local chronic inflammation and tumor neovascularization in human prostate cancer. Clin. Cancer Res. 11: 3250-3256.
Weitzman, S.A. \& Gordon, L.I. 1993. Inflammation and cancer: Role of phagocyte-generated oxidants in carcinogenesis. Blood 76: 655-663.

Wolff, H., Saukkonen, K., Anttila, S., Karjalainen, A., Vainio, H. \& Ristimaki, A. 1998. Expression of cyclooxygenase-2 in human lung carcinoma. Cancer Res. 58: 4997-5001.

Yoshimura, R., Sano, H., Masuda, C., Kawamura, M., Tsubouchi, Y., Chargui, J., Yoshimura, N., Hla, T. \& Wada, S. 2000 Expression of cyclooxygenase-2in prostate carcinoma. Cancer 89: 589-596.

Zha, S., Gage, W., Sauvageot, J., Elizabeth, A., Mathew, J., Charles, M., Dennis, A., William, G., Angelo, M. \& Charles, M. 2001. Cyclooxygenase-2 is up-regulated in proliferative inflammatory atrophy of the prostate, but not in prostatic carcinoma. Cancer Res. 61: 8617-8623.

Zimmermann, K.C., Sarbia, M., Weber, A.A., Borchard, F., Gabbert, H.E. \& Schrör, K. 1999. Cyclooxygenase-2 expression in human esophageal carcinoma. Cancer Res. 59: 198-204.

Mohd Rohaizad Md Roduan* \& Norhafizah Mohtarrudin Department of Pathology

Faculty of Medicine and Health Sciences

Universiti Putra Malaysia

43400 Serdang, Selangor Darul Ehsan

Malaysia

\section{Chong Pei Pei}

Department of Biomedical Sciences

Faculty of Medicine and Health Sciences

Universiti Putra Malaysia

43400 Serdang, Selangor Darul Ehsan

Malaysia

Malina Osman

Department of Medical Microbiology \& Parasitology

Faculty of Medicine and Health Sciences

Universiti Putra Malaysia

43400 Serdang, Selangor Darul Ehsan

Malaysia

Noraini Mohd Dusa

Department of Pathology, Hospital Kuala Lumpur

Jalan Pahang, 50588 Kuala Lumpur

Malaysia

*Corresponding author; email: ijad_27@yahoo.com

Received: 17 May 2013

Accepted: 22 December 2014 